\title{
Application of concrete slurry waste in cement screeds
}

\author{
Pavel Reiterman ${ }^{1}$, Martin Keppert ${ }^{2}$ \\ Faculty of Civil Engineering, Czech Technical University in Prague, Prague, Czech Republic \\ E-mail: ${ }^{1}$ pavel.reiterman@fsv.cvut.cz (corresponding author)
}

\begin{abstract}
Sedimented concrete slurry waste (CSW), containing cement, mineral additives, fine fillers, admixtures and water, is currently a waste without an additional use and has to be fully landfilled. Current CSW management is very expensive and introduces number of environmental risks due to its high $\mathrm{pH}$, exceeding 11.5. This paper deals with the application of two types of CSW as cement replacement in cement screed. The evaluation was carried out in terms of workability and basic mechanical performance of the obtained composites. The applied cement replacement was up to $10 \mathrm{wt} . \%$ due to the negative impact on the rheology of fresh mixtures. Reduced workability consequently caused higher content of air in the fresh mixture. It was reflected by lower values of bulk density in hardened state for both studied CSW. These aspects were the reasons of decreased mechanical performance by approximately $15 \%$ per $5 \mathrm{wt} \%$ of replacement. Conducted experimental program declared significant limits of CSW application in cement based composites, however additional processing of CSW could significantly modify its properties.
\end{abstract}

Keywords: concrete slurry waste, cement screed, waste material.

\section{Introduction}

Portland cement is the most frequently used binding material in building industry worldwide. Its annual production exceeds $4000 \mathrm{Mt}$ (Uwasu, Hara, \& Yabar, 2014; Gao et al., 2015) and is still rising. Unfortunately its production is highly energy intensive and is responsible for about $5 \%$ of global $\mathrm{CO}_{2}$ man-made emissions (Damtoft, Lukasik, Herfort, Sorrentino, \& Gartner, 2008); reduction of $\mathrm{CO}_{2}$ emissions related to concrete production are searched (Kinuthia \& Nidzam 2011; Kubissa, Jaskulski, \& Reiterman, 2017; Schneider, 2015). That is why, reducing of greenhouse gas emissions, frugal natural resources management, and recycling of waste materials have become necessary due to significant negative effects caused by climate change. This necessity was adopted by a number of researchers to discover new technologies focused on the transition to an energy-efficient, low-carbon economy, and reuse of existing materials - recycling (Dousova et al., 2016; Dvorak, Dolak, Vsiansky, \& Dobrovolny, 2016; Hora \& Reiterman, 2016).

Concrete is the second most used substance on Earth, its regional production is highly dependent on the actual economic situation, but global annual production is approximately 2.0 t per capita (Hasanbeigi, Price, \& Lin, 2012; Liu et al., 2018). Unfortunately, it is estimated, that due to poor workmanship, composition modification, overordering and other related problems, in the range $1-4 \mathrm{wt} . \%$ of total concrete production result in waste (Xuan et al., 2016a, 2016b, 2016c; Kou, Zhan, \& Poon, 2012). This fresh concrete is partially recycled by using techniques for aggregate reclaim, however fine residues are stocked in the pits, Figure 1, from which just batch water is reused (Correira et al., 2009). However, alkaline character of CSW could be successfully exploited for various environmental friendly techniques (Hossain, Xuan, \& Poon, 2017; Paria \& Yuet, 2006; Tsunashima, Iizuka, Akimoto, Hongo \& Yamasaki, 2012). Low stability of CSW due to the high content of lime is crucial factor blocking its massive application in concrete industry. Audo, Mahieux, and Turcry (2016) focused their research on the direct utilization of CSW to concrete production. The significant problem of CSW is fluctuating activity, which highly depends on the composition of produced concrete, predominantly on the content of clinker. Powder resulted from CSW was used for the concrete production, however such application is not very effective, there were severe problems with workability of the new concrete mix leading to the increase of plasticizer dose. These findings were confirmed by Vieira and Figueiredo (2016), who accent increased need of water and consequent lower mechanical properties of concrete. Similar idea was also studied by Hossain et al. (2017), including the life cycle analysis (LCA) of the new products. However, durability tests have not been carried out yet.

(C) 2019 Authors. Published by VGTU Press. This is an open-access article distributed under the terms of the Creative Commons Attribution (http://creativecommons.org/licenses/by/4.0/) License, which permits unrestricted use, distribution, and reproduction in any medium, provided the original author and source are credited. 


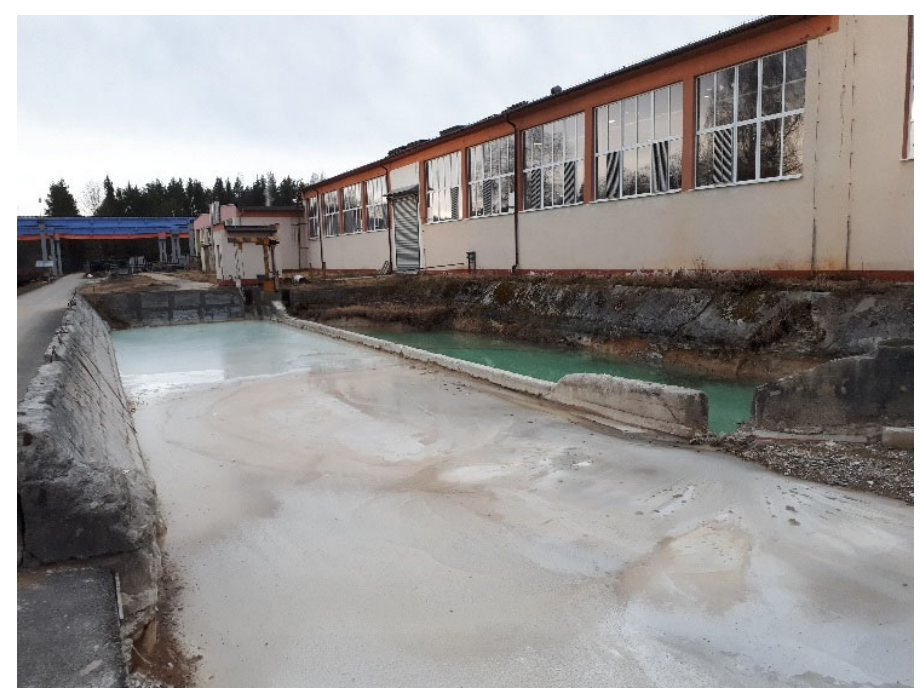

Figure 1. Deposite of concrete slurry waste

\section{Experimental program}

Performed experimental program was focused on the assessment of the application of CSW as alternative filler in cement screeds. Two types of CSW were used, which differed by their age. The first one (SM-A) was extracted on the end the work shift and the second one was extracted from the deposit (SM-B). Both of them were dried in normal laboratory conditions, crushed and sieved up to $\mathrm{D}_{\max }$ of $0.5 \mathrm{~mm}$. The phase composition of used materials was examined in reflection mode by help of X-ray diffractometer PANalytical Aeris, equipped by $\mathrm{Co}_{\mathrm{K} \alpha}$ tube operating at $40 \mathrm{kV}$ and $7.5 \mathrm{~mA}$. The incident beam path consisted of beta-filter iron, Soller slits $0.04 \mathrm{rad}$ and divergence slit $1 / 2^{\circ}$. The diffracted beam path was equipped with $9 \mathrm{~mm}$ anti-scatter slit and Soller slits $0.04 \mathrm{rad}$. The used detector was PIXcel1D-Medipix 3 detector with active length $5.542^{\circ}$. The scan ranged from 5 to $85^{\circ}$, step size $0.0027^{\circ}$, counting time 2.0325 s. Data were evaluated by Profex software (ver. 3.12.1) and quantified by Rietveld method.

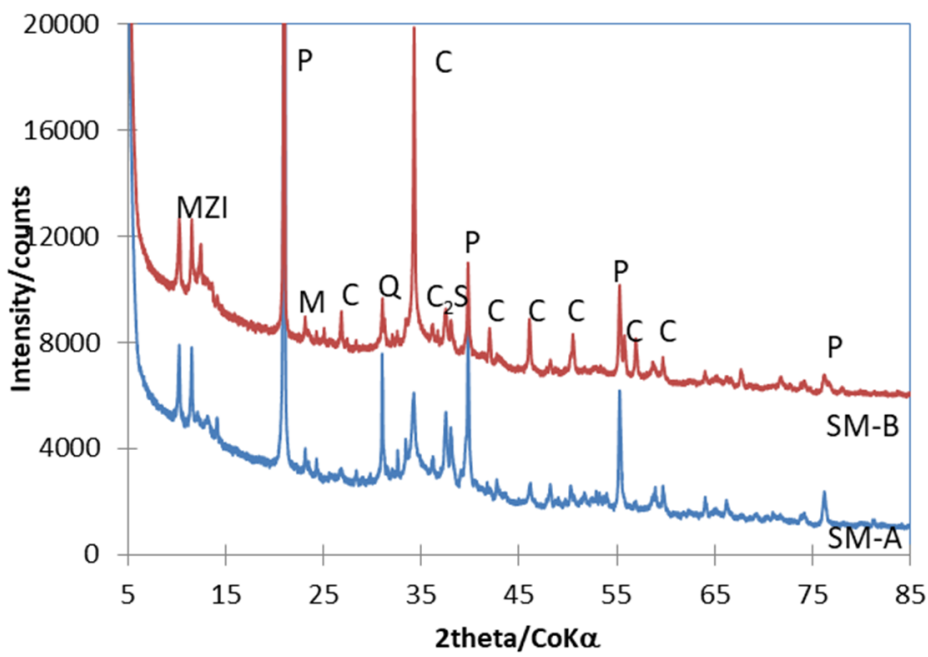

Figure 2. X-ray diffractograms of SM-A and SM-B samples. $\mathrm{P}=$ portlandite, $\mathrm{C}=$ calcite, $\mathrm{M}=$ muscovite, $\mathrm{Z}=$ zeolites (clinoptilolite and heulandite), $\mathrm{I}=$ illite, $\mathrm{Q}=$ quartz, $\mathrm{C}_{2} \mathrm{~S}=$ dicalcium silicate)

The recorded X-ray diffractograms (Figure 2) show difference in both samples; the most apparent is opposite ratio of portlandite and calcite content - as one can expect the older (SM-B) sample contains lower amount of portlandite compared to the "more fresh" sample SM-A (Table 1). Both samples further contain residuals of the used Portland cement and part of fine portion of aggregates. The highest content was found for muscovite, naturally forming small species in sand and gravel; quartz and albite were detected as well. Sort of interesting is presence of two zeolite minerals (clinoptilolite and heulandite) coming again from aggregates. Illite, a common clay mineral, comes from the used sand. 
Table 1. Mineralogical composition of studied CSWs

\begin{tabular}{|c|l|c|c|}
\hline Phase & \multicolumn{1}{|c|}{ Chemical formula } & SM-A & SM-B \\
\hline C3S & $3{\mathrm{CaO} . \mathrm{SiO}_{2}}_{2}$ & 3.6 & 11.9 \\
\hline $\mathrm{C} 2 \mathrm{~S}$ & $2 \mathrm{CaO} .2 \mathrm{SiO}_{2}$ & 17.2 & 2.2 \\
\hline $\mathrm{C} 3 \mathrm{~A}$ & $3 \mathrm{CaO} . \mathrm{Al}_{2} \mathrm{O}_{3}$ & 4.5 & 5.3 \\
\hline C4AF & $4 \mathrm{CaO} . \mathrm{Al}_{2} \mathrm{O}_{3} \cdot \mathrm{Fe}_{2} \mathrm{O}_{3}$ & 10.4 & 11.3 \\
\hline Portlandite & $\mathrm{Ca}(\mathrm{OH})_{2}$ & 18.2 & 24.8 \\
\hline Calcite & $\mathrm{CaCO}$ & 7.4 & 4.3 \\
\hline Quartz & $\mathrm{SiO}_{2}$ & 2.7 & 4.8 \\
\hline Albite & $\mathrm{NaAlSi}_{3} \mathrm{O}_{8}$ & 4.4 & 12.8 \\
\hline Muscovite & $\mathrm{KAl}_{2}\left(\mathrm{AlSi}{ }_{3} \mathrm{O}_{10}\right)\left(\mathrm{F}, \mathrm{OH}_{2}\right.$ & 25.8 & 2.9 \\
\hline Illite & $\mathrm{K}_{0.65} \mathrm{Al}{ }_{2.0}\left(\mathrm{Al}_{0.65} \mathrm{Si}_{3.35} \mathrm{O}_{10}\right)\left(\mathrm{OH}_{2}\right)_{2}$ & 0.6 & 6.9 \\
\hline Heulandite & $(\mathrm{Na}, \mathrm{Ca}, \mathrm{K})_{6}\left(\mathrm{Si}_{2}, \mathrm{Al}\right)_{36} \mathrm{O}_{72} \cdot 22 \mathrm{H}_{2} \mathrm{O}$ & 2.7 & 8.2 \\
\hline Clinoptilolite & $\left(\mathrm{Na}, \mathrm{K}, \mathrm{Ca}_{2-3} \mathrm{Al}_{3}\left(\mathrm{Al}, \mathrm{Si}_{2} \mathrm{Si}_{13} \mathrm{O}_{36} \cdot 12 \mathrm{H}_{2} \mathrm{O}\right.\right.$ & 2.4 & \\
\hline
\end{tabular}

Obtained CSWs in form of powder were applied as a Portland cement replacement by $5 \mathrm{wt} . \%$ and $10 \mathrm{wt} . \%$. Pure siliceous sand of grading 0-4 mm was used as an aggregate, its gradation curve is shown in Figure 3. The composition is introduced in Table 2. All dry components were homogenized at first in laboratory mixer, after that the water was added. The dosage of water was similar for all studied mixture. The consistency was determined in accordance with EN 1015-3 (1999) using the mortar flow table. Content of air in the fresh mixture was determined by pressere method according to EN 1015-7 (1999). The rest of fresh mixtures was used for the production of prisms $40 \times 40 \times 160 \mathrm{~mm}$.

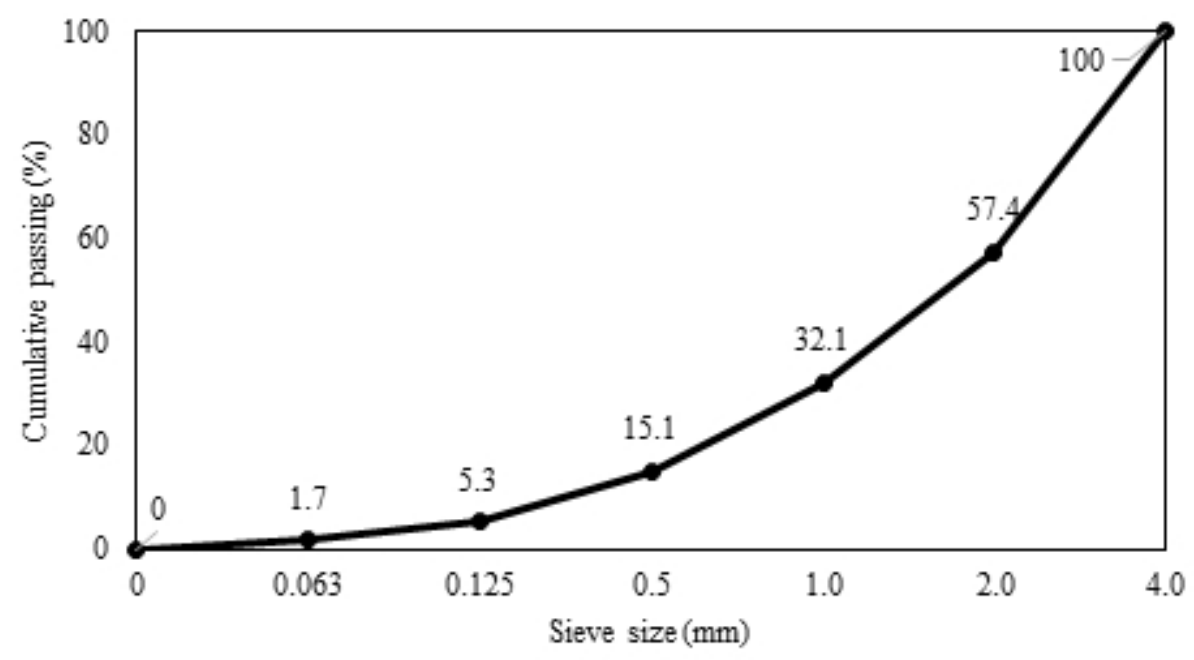

Figure 3. Passing of used siliceous sand

Table 2. Composition of screed mixtures $\left(\mathrm{kg} / \mathrm{m}^{3}\right)$

\begin{tabular}{|c|c|c|c|c|c|}
\hline & SM-R & SMA-05 & SMA-10 & SMB-05 & SMB-10 \\
\hline CEM I 52.5 R & 393 & 373 & 353 & 373 & 353 \\
\hline CSW & 0 & 20 & 40 & 20 & 40 \\
\hline Sand 0 - 4 mm & 1650 & 1650 & 1650 & 1650 & 1650 \\
\hline Water & 215 & 215 & 215 & 215 & 215 \\
\hline Air content & 5.2 & 6.4 & 5.2 & 7.0 & 6.8 \\
\hline Consistency & 110 & 108 & 95 & 108 & 102 \\
\hline
\end{tabular}

All specimens were kept in normal laboratory condition for 28 days, after that the basic physical and mechanical properties were determined. The bulk density was calculated on the basis of actual dimensions and weight of single set 
of specimens. Flexural strength was carried out as three-point bending test with support span $100 \mathrm{~mm}$. Prisms fragments were used for the determination of compressive strength.

\section{Results and discussion}

Studied CSW were applied as partial replacement of Portland cement; their application had significant influence on the properties of fresh mixtures, what is well visible in Table 3. It is evident, that the application of CSW reduced workability and increased content of air in fresh mixture. The lowest applied replacement achieved nearly similar workability as control mixture, however additional increase of CSW led to essential loss of workability; approximately by $12 \%$. Nevertheless, SM-A, which performed "fresh" CSW, exihited more negative influence on the fresh screeed in terms of workability. Likely decay in workability was directly related to the air-entraining. The loss of workability is probably caused by the higher content of reactive compoments in SM-A.

Table 3. Properties of fresh mixtures

\begin{tabular}{|c|c|c|c|c|c|}
\hline & SM-R & SMA-05 & SMA-10 & SMB-05 & SMB-10 \\
\hline Air content & 5.2 & 6.4 & 5.2 & 7.0 & 6.8 \\
\hline Consistency & 110 & 108 & 95 & 108 & 102 \\
\hline
\end{tabular}

Reduced properties in fresh state correspond with achieved values of bulk density after 28 days in hardened state, what is shown in Figure 4. The highest bulk density was reached by control mixture, slight decrease exhibited waste material extracted from the deposite in the lowest applied replacement. The "fresh" CSW significantly reduced the values of bulk density. CSW obtained from the deposit (SM-B), where was stored for months, had minimal influence on the bulk density in the lowest dosage. Obtained mechanical properties are introduced in Figure 5.

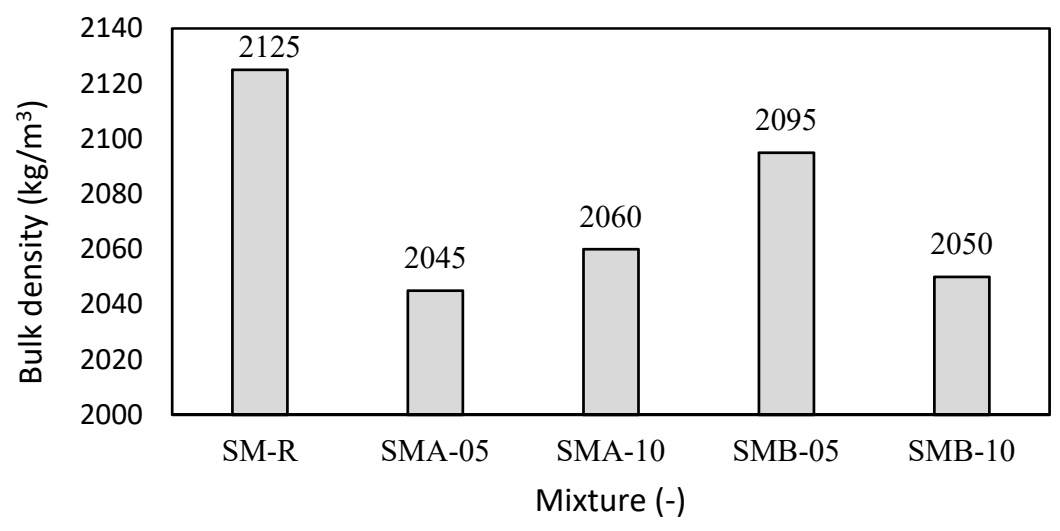

Figure 4. Passing of used siliceous sand

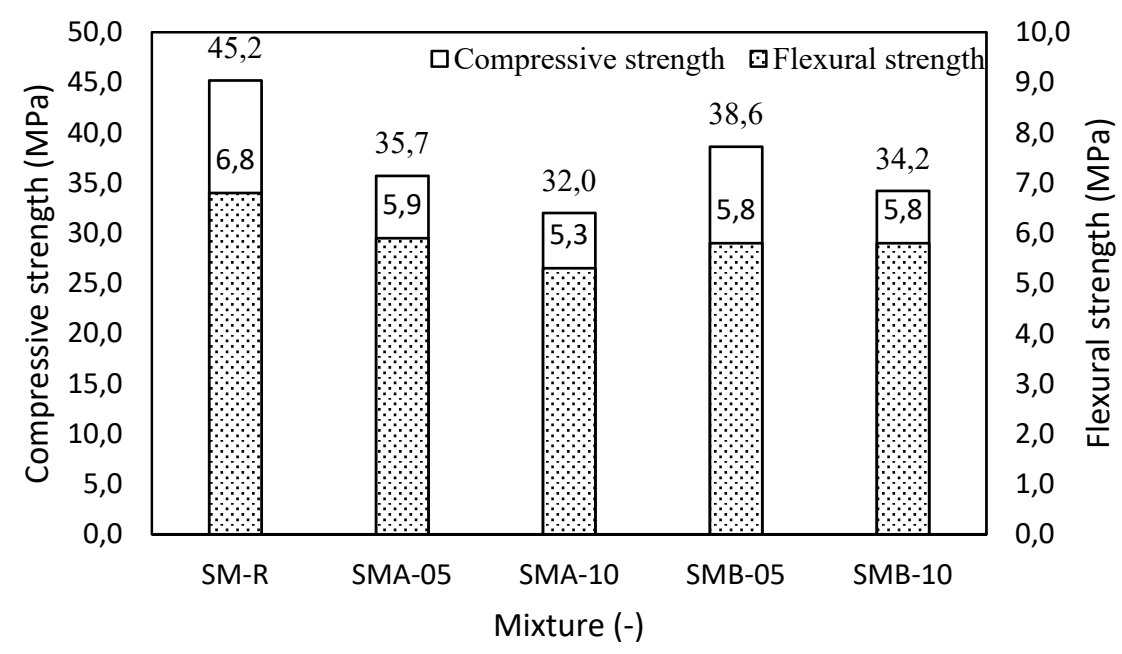

Figure 5. Final mechanical properties of studied screeds 
Applied CSWs exhibited nearly similar influence on cement screeds in terms of mechanical properties, what means, that significant differences in mineralogical composition of both CSW were not important. In general, both studied CSW led to the gradual reduction of mechanical properties proportionaly to the applied replacement. The decay of flexural strength was for 5 and $10 \mathrm{wt} . \%$ approximately $14 \%, 22 \%$ respectively. In terms of compressive strength was the gradual decay $20 \%$ and $27 \%$ for replacement by CSW by $5 \mathrm{wt} . \%$, and $10 \mathrm{wt} . \%$ respectively. The obtained mechanical performance well corresponds with the consistency of fresh mixtures.

\section{Conclusions}

Present work was focused on the application of waste material, which is generated in the concrete plants and currently has no practical utilization. The waste is frequently stoked on landfills and due to its high $\mathrm{pH}$ performs a hazardous waste. The study dealt with the treatment of CSW by drying and milling and consequent application of resulted material as partial cement replacement in screeds.

It was declared, that CSW exhibited significantly different properties according to its age. CSW extracted from the deposit after months of storing contained lower amount of reactive components from cement, additionaly part of portlandite transformed to calcite. However, both studied CSW were highly alkaline. Their application to cement screed caused significant air-entrainment, what led to the decay of bulk density. The mineralogical differences in single CSW affected the consistency of fresh mixtures. The older CSW seems to be more suitable in terms of workability for studied application. Replacement of cement by CSW caused, in general, decay of mechanical performance. I was quite interesting, that the influence of both CSW of different composition was nearly similar. The lowest applied replacement led to reduction of compressive strength by $20 \%$, what introduces reduction of strength class. This fact is highly reduces practical potential of CSW for studied application.

CSW is waste material, which will be further generated during the concrete production during following years, hence it is very important to find out some suitable and economic ways for its practical use. Its further utilization in building industry would be preferred with respect to the nature of this waste. Following research will be focused on the formulation of environmentaly friendly composites incorporating CSW and active mineral additives, such as fly ash, where could be conveniently exploited alkaline character of CSW. Suggested research could contribute to the reduction of potential negative risks of landfilling of these hazardous materials and could increase the efficiency of utilizing of natural resources.

\section{Acknowledgements}

Present work was gratefully supported by Czech Science Foundation under the project No: 19-11027S.

\section{References}

Audo, M., Mahieux, P.-Y., \& Turcry, P. (2016). Utilization of sludge from ready-mixed concrete plants as a substitute for limestone fillers. Construction and Building Materials, 112, 790-799. https://doi.org/10.1016/j.conbuildmat.2016.02.044

Correia, S. L., Souza, F. L., Dienstmann, G., \& Segadães, A. M. (2009). Assessment of the recycling potential of fresh concrete waste using a factorial design of experiments. Waste Management, 29(11), 2886-2891. https://doi.org/10.1016/j.wasman.2009.06.014

Damtoft, J. S., Lukasik, J., Herfort, D., Sorrentino, D., \& Gartner, E. M. (2008). Sustainable development and climate change initiatives. Cement and Concrete Research, 38(2), 115-127. https://doi.org/10.1016/j.cemconres.2007.09.008

Dousova, B., Kolousek, D., Keppert, M., Machovic, V., Lhotka, M., Urbanova, M., Brus, J., \& Holcova, L. (2016). Use of waste ceramics in adsorption technologies. Applied Clay Science, 134, 145-152. https://doi.org/10.1016/j.clay.2016.02.016

Dvorak, K., Dolak, D., Vsiansky, D., \& Dobrovolny, P. (2016). Evaluation of the grindability of recycled glass in the production of blended cements. Materiali in Tehnologije, 50(5), 729-734. https://doi.org/10.17222/mit.2015.184

European Committee for Standartization. (1999). Methods of test for mortar for masonry. Determination of consistence of fresh mortar (by flow table) (EN 1015-3).

European Committee for Standartization. (1999). Methods of test for mortar for masonry. Determination of air content of fresh mortar (EN 1015-7).

Gao, T., Shen, L., Shen, M., Chen, F., Liu, L., \& Gao, L. (2015). Analysis on differences of carbon dioxide emission from cement production and their major determinants. Journal of Cleaner Production, 103, 160-170. https://doi.org/10.1016/j.jclepro.2014.11.026

Hasanbeigi, A., Price, L., \& Lin, E. (2012). Emerging energy-efficiency and $\mathrm{CO}_{2}$ emission-reduction technologies for cement and concrete production: A technical review. Renewable and Sustainable Energy Reviews, 16(8), 6220-6238. https://doi.org/10.1016/j.rser.2012.07.019

Hora, M., \& Reiterman, P. (2016). Assessment of the air-entraining effect of rubber powder and its influence on the frost resistance of concrete. Revista Romana de Materiale - Romanian Journal of Materials, 43(3), 327-333. 
Hossain, M. U., Xuan, D., \& Poon, C. S. (2017). Sustainable management and utilisation of concrete slurry waste: A case study in Hong Kong. Waste Management, 61, 397-404. https://doi.org/10.1016/j.wasman.2017.01.038

Kinuthia, J. M., \& Nidzam, R. M. (2011). Towards zero industrial waste: Utilisation of brick dust waste in sustainable construction. Waste Management, 31(8), 1867-1878. https://doi.org/10.1016/j.wasman.2011.03.020

Kou, S., Zhan, B., \& Poon, C. (2012). Feasibility study of using recycled fresh concrete waste as coarse aggregates in concrete. Construction and Building Materials, 28(1), 549-556. https://doi.org/10.1016/j.conbuildmat.2011.08.027

Kubissa, W., Jaskulski, R., \& Reiterman, P. (2017). Ecological concrete based on blast-furnace cement with incorporated coarse recycled concrete aggregate and fly ash addition. Journal of Renewable Materials, 5(1), 53-61. https://doi.org/10.7569/JRM.2017.634103

Liu, W., Su, S., Xu, K., Chen, Q., Xu, J., Sun, Z., ..., \& Xiang, J. (2018). $\mathrm{CO}_{2}$ sequestration by direct gas-solid carbonation of fly ash with steam addition. Journal of Cleaner Production, 178, 98-107. https://doi.org/10.1016/j.jclepro.2017.12.281

Paria, S., \& Yuet, P. K. (2006). Solidification-stabilization of organic and inorganic contaminants using portland cement: A literature review. Environmental Reviews, 14(4), 217-255. https://doi.org/10.1139/A06-004

Schneider, M. (2015). Process technology for efficient and sustainable cement production. Cement and Concrete Research, 78, 1423. https://doi.org/10.1016/j.cemconres.2015.05.014

Tsunashima, Y., Iizuka, A., Akimoto, J., Hongo, T., \& Yamasaki, A. (2012). Preparation of sorbents containing ettringite phase from concrete sludge and their performance in removing borate and fluoride ions from waste water. Chemical Engineering Journal, 200-202, 338-343. https://doi.org/10.1016/j.cej.2012.06.064

Uwasu, M., Hara, K., \& Yabar, H. (2014). World cement production and environmental implications. Environmental Development, 10, 36-47. https://doi.org/10.1016/j.envdev.2014.02.005

Vieira, L. de B. P., \& de Figueiredo, A. D. (2016). Evaluation of concrete recycling system efficiency for ready-mix concrete plants. Waste Management, 56, 337-351. https://doi.org/10.1016/j.wasman.2016.07.015

Xuan, D., Zhan, B., \& Poon, C. S. (2016a). Development of a new generation of eco-friendly concrete blocks by accelerated mineral carbonation. Journal of Cleaner Production, 133, 1235-1241. https://doi.org/10.1016/j.jclepro.2016.06.062

Xuan, D., Zhan, B., Poon, C. S., \& Zheng, W. (2016b). Carbon dioxide sequestration of concrete slurry waste and its valorisation in construction products. Construction and Building Materials, 113, 664-672. https://doi.org/10.1016/j.conbuildmat.2016.03.109

Xuan, D., Zhan, B., Poon, C. S., \& Zheng, W. (2016c). Innovative reuse of concrete slurry waste from ready-mixed concrete plants in construction products. Journal of Hazardous Materials, 312, 65-72. https://doi.org/10.1016/j.jhazmat.2016.03.036 